\title{
Laporan Kasus Kehamilan pada Minggu Ke-34/35 dengan Covid-19, Diagnosis dan Penatalaksanaannya
}

\author{
Ratna Widyastuti ${ }^{1,2^{*}}$, Arief Prijatna ${ }^{1,2}$ \\ 1) Departemen Obstetri dan Ginekologi, Fakultas Kedokteran, Universitas Muhammadiyah Surakarta, Indonesia \\ 2) RSUD Dr. Harjono S. Ponorogo, Jawa Timur, Indonesia \\ *Corresponding author: ratnawidyastutispog@gmail.com
}

\begin{abstract}
Coronavirus disease 2019 (COVID-19) is an infectious disease that has caused a global pandemic. At the time of writing, the knowledge surrounding the COVID-19 and its relation to pregnancy and fetus is still limited. This case report will discuss COVID-19 case in a 24 years old woman in her 34/35 weeks of pregnancy. Her chest X-ray showed bilateral pneumonia, whereas the PCR SARS CoV-2 test gave a positive result. The patient underwent an elective cesarean section. The baby was born with a birth weight of 2700 grams, an Apgar score of 7 9, and without neonatal abnormality. The patient was then treated in an isolation room with collaborative care from various specialists. She did not exhibit intrapartum and postpartum complications. Both the mother and baby had been safely discharged from the hospital. This paper puts a great emphasis on the importance of giving optimum therapy to pregnant women infected with COVID-19.
\end{abstract}

Keywords: covid-19, outcome, pregnancy

\begin{abstract}
ABSTRAK
Coronavirus disease 2019 (COVID-19) adalah penyakit menular yang telah menyebabkan pandemi global. Pada saat penulisan, pengetahuan seputar COVID-19 dan hubungannya dengan kehamilan dan janin masih terbatas. Laporan kasus ini akan membahas COVID-19 pada seorang wanita berusia 24 tahun pada usia kehamilan 34/35 minggu. Hasil pemeriksaan rontgen dada menunjukkan adanya pneumonia bilateral, sedangkan tes Polymerase Chain Reaction (PCR) SARS CoV-2 memberikan hasil positif. Pasien menjalani operasi caesar elektif. Bayi lahir dengan berat badan lahir 2700 gram, skor Apgar 7-9, dan tanpa kelainan neonates, selanjutnya pasien dirawat di ruang isolasi dengan perawatan kolaboratif dari berbagai spesialis, tidak mengalami komplikasi intrapartum maupun postpartum. Ibu dan bayi dipulangkan dari rumah sakit dalam kondisi baik. Artikel ini sangat menekankan pentingnya memberikan terapi yang optimal kepada ibu hamil yang terinfeksi COVID-19.
\end{abstract}

Kata kunci: covid-19, hasil, kehamilan

\section{PENDAHULUAN}

Penyakit Coronavirus 2019 (COVID-19) adalah penyakit infeksi yang disebabkan oleh novel coronavirus, sekarang disebut acute respiratory syndrome coronavirus 2 (SARS-CoV-2). Kemunculan virus ini 
telah menyebabkan pandemi global dan menjadi masalah kesehatan masyarakat serius (1).

Sejak diumumkan pertama kali ada di Indonesia pada 2 Maret 2020, kasus COVID-19 meningkat jumlahnya dari waktu ke waktu sehingga memerlukan perhatian (2). Pada praktiknya di masa pandemi, tata laksana COVID-19 diperlukan kerjasama banyak stakeholders untuk menanganinya dan diperlukan upaya pencegahan transmisi virus SARS-CoV-2 baik dari tenaga medis maupun lingkungan sekitarnya serta pengobatan terhadap pasien. Sampai saat ini, pengetahuan tentang infeksi COVID-19 dalam hubungannya dengan kehamilan dan janin masih terbatas dan belum ada rekomendasi yang spesifik untuk penanganan ibu hamil dengan COVID-19 (3).

Pengetahuan mengenai patofisiologi infeksi COVID-19 pada kehamilan masih terbatas karena data dan penelitian masih terus dilakukan. Virus ditransmisikan melalui droplet respiratorik. SARS-CoV-2 dalam droplet yang terhirup akan berikatan dengan sel-sel epitel di saluran respiratorik melalui reseptor ACE-2 melalui subunit S1 protein spike virus. Hal ini diikuti oleh perubahan konformasional protein spike yang mengakibatkan terjadinya fusi antara subunit S2 protein spike virus dan reseptor sehingga terjadi endositosis. Masuknya nucleocapsid virus ke dalam sel inang diikuti oleh replikasi RNA virus, transkripsi, dan translasi. Proses selanjutnya adalah biosintesis protein di sitoplasma dan pelepasan partikel virus baru melalui eksositosis (4).

Infeksi COVID-19 memicu terjadinya respon imun terbatas, namun sekitar seperlima pasien mengalami keterlibatan saluran napas bawah, di mana terjadi invasi dan infeksi sel epitel alveolar tipe II. Hal ini diikuti oleh pelepasan mediator inflamatorik (IL-1, IL-6, IL-8, IL10 , IL-12, TNF- $\alpha$, dan IFN- $\gamma$ ) yang dapat menyebabkan terjadinya cytokine storm (4). Pada trimester awal kehamilan, ibu hamil berada dalam kondisi pro inflamatorik di mana banyak ditemukan sitokin tipe 1 (implantasi), masuk trimester kedua kondisi akan cenderung anti inflamatorik (sitokin tipe 2), sedangkan pada akhir kehamilan akan kembali dalam keadaan pro-inflamatorik (sitokin tipe 1). Apakah wanita hamil menjadi rentan pada awal dan akhir kehamilan masih dalam penelitian (5).

Laporan awal kasus infeksi COVID19 pada ibu hamil di Wuhan melaporkan bahwa dari sembilan ibu hamil dengan infeksi COVID-19 memiliki presentasi klinis yang sama dengan pasien dewasa yang tidak hamil serta tidak ada bukti adanya transmisi vertikal pada pasien (6). Akan tetapi, berdasarkan systematic review yang dilakukan oleh Kotlyar et al menunjukkan bahwa transmisi vertikal COVID-19 mungkin terjadi terutama pada trimester ketiga (7). Meskipun demikian, dalam guideline yang dikeluarkan oleh NIH, ibu hamil yang diduga maupun terkonfirmasi mengalami infeksi COVID19 tidak wajib dilakukan operasi caesar, melainkan harus berdasarkan indikasi obstetrik baik fetal maupun maternal (8).

WHO merekomendasikan pemeriksaan molekuler untuk seluruh pasien yang terduga terinfeksi COVID-19 metode yang dianjurkan adalah metode deteksi molekuler NAAT (Nucleic Acid Amplification Test) seperti pemeriksaan RT-PCR (9). Hingga saat ini belum ada obat yang spesifik untuk mengobati COVID-19. Pengobatan ditujukan sebagai terapi simptomatis dan suportif. Ada beberapa kandidat obat tertentu yang masih 
diteliti melalui uji klinis. Dalam artikel ini, kami melaporkan kasus COVID-19 pada ibu hamil dengan usia kehamilan 34/35 minggu dan penanganan yang kami berikan sehingga diperoleh outcome yang baik pada ibu maupun bayinya.

\section{LAPORAN KASUS}

Seorang wanita berusia 24 tahun datang ke PONEK RSUD Dr. Harjono S Kabupaten Ponorogo dengan kondisi hamil usia 34/35 minggu, perut kontraksi disertai demam, badan lemas, batuk dan sesak nafas. Keadaan umum compos mentis, sesak nafas, gizi sedang, dengan laju pernapasan $24 \mathrm{kali} / \mathrm{menit}$, saturasi oksigen 93\%. Riwayat penyakit dahulu, diabetes mellitus (DM), jantung, dan penyakit paru disangkal. Pada pemeriksaan paru didapatkan bronkovesikuler dan ronchi kasar pada kedua lapang paru. Dari pemeriksaan obstetri didapatkan tinggi fundus uteri 3 jari di bawah processus xiphoideus, punggung kiri, kepala belum masuk panggul, denyut jantung janin +169 kali/menit, his + jarang, dan belum ada pembukaan.

Dari hasil pemeriksaan laboratorium, swab antigen positif, dilanjutkan dengan swab PCR hasil positif (CT value Gen orf $3 a=17 \mathrm{~N}=13$ ). Hematologi Leukosit 12,10 x $10^{3} / \mu$ L. Koagulasi D-Dimer kuantitatif $1879,50 \mathrm{mg} / \mathrm{mL}(\mathrm{N}=<500)$. Kimia klinik gula darah sewaktu (GDS) $310 \mathrm{mg} / \mathrm{dL}$ (N=70-180). Pemeriksaan foto rontgen dada menunjukkan adanya pneumonia bilateral. Pasien dirawat di ruang isolasi COVID-19 oleh kolaborasi antara dokter spesialis obgyn, dokter spesialis paru, dokter spesialis penyakit dalam dan dokter spesialis jantung. Pasien memperoleh terapi cairan, terapi oksigen, tokolitik, dan maturasi paru untuk bayinya. Dari spesialis paru, pasien memperoleh terapi antibiotik, antivirus, multivitamin, steroid dan obatobatan untuk meningkatkan imunitas. Spesialis penyakit dalam memberikan obatobatan untuk meregulasi gula darah. Sedangkan spesialis jantung memberikan obat-obatan untuk mengatasi gangguan koagulasi.

Setelah perawatan hari keempat, kondisi pasien membaik, sesak berkurang, saturasi oksigen $99 \%$, gula darah sudah normal 97 mg/dL. Namun pasien mengeluh air ketuban merembes. Atas pertimbangan keluarnya air kawah dan belum adanya tanda-tanda persalinan, kehamilan diakhiri dengan operasi Sectio-Caesarea Trans Peritoneal (SCTP) secara elektif. Pelaksanaan SCTP dilakukan di kamar operasi bertekanan negatif. Semua petugas menggunakan alat pelindung diri level 3 sesuai dengan protokol kesehatan yang dianjurkan pemerintah (standar WHO) untuk mencegah penularan infeksi COVID19 dari pasien ke petugas. Bayi laki-laki terlahir dengan berat lahir 2700 gram, skor Apgar 7-9. Hasil swab PCR pada bayi didapatkan hasil negatif. Kemudian dilakukan rawat terpisah antara ibu dan bayi, namun ibu masih menyusui bayinya dengan menggunakan masker dan mencuci tangan sebelumnya. Kondisi ibu selama proses persalinan dan post-partum baik. Empat hari pasca SCTP dilakukan PCR ulang, sebelum pulang hasil PCR ibu positif, pasien pulang disarankan untuk isolasi mandiri di rumah. Ibu dan bayi pulang dalam kondisi baik.

\section{PEMBAHASAN}

Kasus ini menggambarkan presentasi klinis pada pasien hamil dengan infeksi COVID19. Beberapa tantangan muncul dalam kasus ini adalah penegakan diagnosis yang cepat dan tepat dan penatalaksanaan dalam kehamilan maupun persalinan sehingga 
dapat menurunkan angka kematian ibu dan bayi. Diagnosis COVID-19 dalam kehamilan ditegakkan bermula dari anamnesis pasien. Saat datang dengan keluhan hamil 34/35 minggu dengan keluhan perut kontraksi disertai dengan badan lemas, demam, batuk dan sesak nafas. Sejak masa pandemi, setiap pasien rawat inap di rumah sakit, dilakukan pemeriksaan swab antigen dan ternyata hasil swab antigen positif dan didiagnosis suspek COVID-19 dan pasien dirawat di ruang isolasi COVID-19. Diagnosis pasti dari COVID-19 tersebut diperoleh dari hasil swab PCR yang menunjukkan hasil positif. WHO merekomendasikan pemeriksaan molekuler untuk seluruh pasien yang terduga terinfeksi COVID-19. Metode yang dianjurkan adalah metode deteksi molekuler NAAT (Nucleic Acid Amplification Test) seperti pemeriksaan RT-PCR (9).

Pasien datang dalam kondisi sudah terjadi komplikasi pada parunya dengan gejala sesak nafas, batuk, dan demam. Pada pemeriksaan fisik didapatkan bronkovesikuler yang disertai ronchi kasar pada kedua lapang paru, saturasi oksigen $93 \%$, dan hasil foto rontgen dada yang menunjukkan adanya pneumonia bilateral. Infeksi COVID-19 pada pasien juga berdampak terhadap kehamilannya, yaitu terjadi partus prematurus imminen dan gawat janin (takikardi). Dengan pemberian terapi cairan, terapi oksigen, pemberian maturasi paru, tokolitik, kondisi janin membaik dan kencang-kencang pada kehamilan berkurang.

Hingga saat ini belum ada obat yang spesifik untuk mengobati COVID-19. Pengobatan ditujukan sebagai terapi symptomatis dan suportif. Ada beberapa obat tertentu masih diteliti melalui uji klinis (10). Sehingga terapi yang diberikan pada pasien ini sudah sesuai dengan rekomendasi dari WHO di mana untuk merawat pasien ini berkolaborasi dengan beberapa dokter yaitu spesialis obgyn, spesialis penyakit dalam, spesialis paru dan spesialis jantung untuk mendapatkan hasil yang optimal. Terapi yang diberikan dari dokter paru dengan pemberian terapi oksigen, menggunakan Non-Rebreathable Mask (NRM) $6 \mathrm{~L} / \mathrm{menit}$, pemberian antibiotik, steroid, antiviral, kombinasi multivitamin, serta obat-obatan yang meningkatkan imunitas, berhubung pasien ini sudah mengalami komplikasi pada paru (pneumonia bilateral). Dalam empat hari perawatan, sesak nafas berkurang, saturasi oksigen $99 \%$, pada saat pulang foto rontgen dada ulang menunjukkan paru sudah kembali normal.

POGI merekomendasikan bahwa penanganan pasien ibu hamil dengan COVID-19 harus dilakukan oleh tim multidisiplin yang meliputi dokter obgyn, penyakit dalam/paru, dokter anestesi, bidan, dokter neonatologi, dan perawat neonatus (5). Kami mengkonsultasikan pasien ke dokter spesialis penyakit dalam karena GDS $310 \mathrm{mg} / \mathrm{dL}$ untuk dilakukan regulasi penurunan gula darah sampai mencapai kadar gula darah normal. Pada pasien ini tidak ada riwayat DM sebelum hamil. Studi terbaru juga menerangkan bahwa virus SARS-CoV-2 dapat menyerang pankreas, merusak sel-sel yang memproduksi dan mengatur insulin sehingga menyebabkan gula darah naik dan terjadi diabetes (11). Kesamaan yang jelas antara COVID-19 dan diabetes adalah keduanya disebabkan oleh peradangan, sehingga bisa menjadi faktor resiko serius yang memungkinkan virus menyerang paru-paru dan pankreas, yang dapat memicu diabetes sebagai komplikasi COVID-19 (11). Pada kasus ini, kami juga 
berkolaborasi dengan spesialis jantung karena didapatkan adanya peningkatan kadar D-Dimer yaitu 1874,50 (N= kurang dari 500). Dari spesialis jantung diberikan obat pengencer darah sehingga dapat mencegah terjadinya pembekuan darah. Studi menunjukkan bahwa kadar D-dimer yang tinggi berhubungan dengan keparahan infeksi COVID-19 dan merupakan prediktor independen mortalitas pasien COVID-19 (12,13). Peningkatan D-Dimer ini diduga disebabkan oleh badai sitokin yang memicu ketidakseimbangan antara pembentukan dan pemecahan bekuan darah (14). Semakin tinggi D-Dimer dalam darah, semakin besar pula risiko pasien COVID19 mengalami penggumpalan darah. Kondisi ini bisa menyebabkan berbagai masalah kesehatan seperti trombosis vena dalam, emboli paru atau stroke $(15,16)$.

Terapi dari bagian obgyn sendiri adalah pemberian obat untuk pematangan paru karena usia kehamilan masih 34 minggu dan pemberian tokolitik karena pada kehamilannya terjadi partus prematurus imminen. Dalam perjalanannya selama empat hari perawatan, pasien mengeluh keluar air kawah (Premature Rupture of Membrane/ketuban pecah dini), dan belum ada pembukaan dari pemeriksaan vaginal touchee. Jadi pada pasien ini sudah terjadi ketuban pecah dini dengan belum terjadinya tanda-tanda persalinan. Untuk menghindari terjadinya infeksi baik pada bayi maupun ibu direncanakan pengakhiran kehamilan secara SCTP elektif. Pelaksanaan SCTP dilakukan di kamar operasi bertekanan negatif. Semua petugas menggunakan APD level 3 sesuai dengan protokol kesehatan yang dianjurkan pemerintah (standar WHO) untuk mencegah penularan infeksi COVID-19 dari pasien ke petugas (17).
Berdasarkan studi epidemiologi dan virologi saat ini membuktikan bahwa COVID-19 utamanya ditularkan dari orang yang bergejala (simptomatik) ke orang lain yang berada jarak dekat melalui droplet (18). Droplet merupakan partikel berisi air dengan diameter $>5 \mu \mathrm{m}$ (19). Penularan droplet terjadi ketika seseorang berada pada jarak dekat (dalam satu meter) dengan seseorang yang memiliki gejala pernafasan. Sehingga droplet beresiko mengenai mukosa (mulut dan hidung) atau konjungtiva (mata). Penularan juga dapat terjadi melalui benda dan permukaan yang terkontaminasi droplet di sekitar orang yang terinfeksi. Oleh karena itu, penularan virus COVID-19 dapat terjadi melalui kontak langsung dengan orang yang terinfeksi dan kontak tidak langsung dengan permukaan atau benda yang digunakan pada orang yang terinfeksi (4).

Dalam konteks COVID-19, transmisi melalui udara dapat dimungkinkan dalam keadaan khusus di mana prosedur atau perawatan suportif yang menghasilkan aerosol seperti intubasi endotrakeal, bronkoskopi, suction, pemberian pengobatan nebulisasi, ventilasi manual sebelum intubasi, mengubah pasien ke posisi tengkurap, memutuskan koneksi ventilator, ventilasi tekanan positif noninvasif $(20,21)$.

Pemilihan SCTP ini diindikasikan berdasarkan indikasi sosial, mengingat kondisi pasien saat itu baru terjadi perbaikan dari infeksi COVID-19. Sejauh ini belum ada bukti yang kuat bahwa salah satu metode persalinan lebih unggul dari metode persalinan yang lain, sehingga pemilihan metode persalinan harus didasarkan atas penilaian per pasien (5). Pasien dilakukan SCTP elektif, bayi lahir laki-laki dengan berat lahir 2700 gram AS 7-9. Bayi dilakukan pemeriksaan swab 
PCR dengan hasil negatif. Tidak ada kelainan kongenital pada bayi. Kesimpulannya tidak terjadi transmisi COVID-19 pada kasus ini. Transmisi vertikal COVID-19 mungkin dapat terjadi, namun kasusnya sangat jarang. Kondisi pasien selama operasi dan masa nifas baik, saturasi oksigen 99\%. Selama perawatan empat hari post operasi, dilakukan swab PCR ulang, hasilnya masih positif, sudah tidak ada keluhan sesak, tidak batuk, $\mathrm{SpO} 2$ $99 \%$, foto thorax normal, D-Dimer normal, pasien dipulangkan untuk isolasi mandiri di rumah. Selama di rumah, bayi dipisah dari ibunya karena hasil PCR bayi negatif. Untuk pemberian ASI, bisa dilakukan dengan secara pumping. Pada saat pumping, ibu cuci tangan bersih dengan antiseptik, pakai masker dan dipastikan mengikuti protokol kesehatan.

\section{SIMPULAN}

Artikel ini menggambarkan kasus COVID19 pada kehamilan yang sudah disertai komplikasi baik pada ibu maupun janinnya. Perawatan ibu hamil yang terkonfirmasi COVID-19 memerlukan kerjasama tim multidisiplin yang terdiri dari dokter obgyn, penyakit dalam/paru, dokter anestesi, bidan, dokter neonatologi, dan perawat neonatus sehingga bisa diperoleh outcome terbaik bagi ibu maupun bayinya. Karena belum ada bukti kuat bahwa metode persalinan yang satu lebih unggul dari metode yang lain, pemilihan metode persalinan lebih baik disesuaikan dengan kondisi masing-masing pasien.

\section{UCAPAN TERIMA KASIH}

Penulis mengucapkan terima kasih kepada RSUD Dr. Harjono S. Ponorogo yang telah memfasilitasi peneliti dalam membuat laporan kasus ini.

\section{KONFLIK KEPENTINGAN}

Penulis tidak memiliki konflik kepentingan, dan tidak ada afiliasi atau koneksi dengan atau dengan entitas atau organisasi apa pun, yang dapat menimbulkan bias dalam diskusi dan kesimpulan naskah.

\section{REFERENSI}

1. Perhimpunan Dokter Paru Indonesia. Pneumonia COVID-19: Diagnosis dan Penatalaksanaan di Indonesia. Journal of the American Pharmacists Association. 2020.

2. Nugraha B, Wahyuni LK, Laswati $\mathrm{H}$, Kusumastuti $\mathrm{P}$, Tulaar AB, Gutenbrunner C. COVID-19 pandemic in Indonesia: Situation and challenges of rehabilitation medicine in Indonesia. Acta Med Indones. 2020 Jul;52(3):299-305.

3. Royal College of Obstetricians and Gynaecologist. Coronavirus (COVID-19) Infection in Pregnancy. 2020;

4. Parasher A. COVID-19: Current understanding of its Pathophysiology, Clinical presentation and Treatment. Postgrad Med J. 2021;97(1147):312-20.

5. Pokja Infeksi Saluran Reproduksi POGI. Rekomendasi Penanganan Infeksi Virus Corona (Covid-19) Pada Maternal (Hamil, Bersalin Dan Nifas) Revisi 2. 2020.

6. Chen H, Guo J, Wang C, Luo F, Yu $\mathrm{X}$, Zhang $\mathrm{W}$, et al. Clinical characteristics and intrauterine vertical transmission potential of COVID-19 infection in nine pregnant women: a retrospective review of medical records. Lancet. 2020;395(10226):809-15. 
7. Kotlyar AM, Grechukhina O, Chen

A, Popkhadze S, Grimshaw A, Tal $\mathrm{O}$, et al. Vertical transmission of coronavirus disease 2019: a systematic review and metaanalysis. Am J Obstet Gynecol. 2020/07/31. 2021 Jan;224(1):3553.e3.

8. National Institutes of Health. Treatment Guidelines Panel. Coronavirus Disease 2019 (COVID19). Nih. 2021;2019.

9. WHO Guidance Note. Laboratory testing for coronavirus disease (COVID-19) in suspected human cases: interim guidance, 11 Setember 2020. World Heal Organ. 2020;(March):20.

10. National Institutes of Health. Coronavirus Disease 2019 (COVID19) Treatment Guidelines. Natl Inst Heal. 2021;

11. Lim S, Bae JH, Kwon H-S, Nauck MA. COVID-19 and diabetes mellitus: from pathophysiology to clinical management. Nat Rev Endocrinol [Internet]. 2021 Jan 13;17(1):11-30. Available from: http://www.nature.com/articles/s415 74-020-00435-4

12. Yu H-H, Qin C, Chen M, Wang W, Tian D-S. D-dimer level is associated with the severity of COVID-19. Thromb Res. 2020/07/27. 2020 Nov;195:219-25.

13. Li Y, Deng Y, Ye L, Sun H, Du S, Huang H, et al. Clinical Significance of Plasma D-Dimer in COVID-19 Mortality. Front Med. 2021 May;8:638097.

14. Mucha SR, Dugar S, McCrae K, Joseph D, Bartholomew J, Sacha GL, et al. Coagulopathy in COVID19: Manifestations and management.
Cleve Clin J Med. 2020 Jul;87(8):461-8.

15. Gómez-Mesa JE, Galindo-Coral S, Montes MC, Muñoz Martin AJ. Thrombosis and Coagulopathy in COVID-19. Curr Probl Cardiol. 2020/11/02. 2021

Mar;46(3):100742.

16. Gupta A, Madhavan M V, Sehgal K, Nair N, Mahajan S, Sehrawat TS, et al. Extrapulmonary manifestations of COVID-19. Nat Med. 2020 Jul;26(7):1017-32.

17. World Health Organization. Rational use of personal protective equipment for COVID-19 and considerations during severe shortages: interim guidance, 23 December 2020. 2020;(December):1-32.

18. Jayaweera $\mathrm{M}$, Perera $\mathrm{H}$, Gunawardana B, Manatunge J. Transmission of COVID-19 virus by droplets and aerosols: A critical review on the unresolved dichotomy. Environ Res. 2020/06/13. 2020 Sep;188:109819.

19. Siegel JD, Rhinehart E, Jackson M, Chiarello L. 2007 Guideline for Isolation Precautions: Preventing Transmission of Infectious Agents in Health Care Settings. Am J Infect Control. 2007 Dec;35(10 Suppl 2):S65-164

20. Tran K, Cimon K, Severn M, PessoaSilva CL, Conly J. Aerosol generating procedures and risk of transmission of acute respiratory infections to healthcare workers: A systematic review. PLoS One. 2012;7(4).

21. WHO. Mask use in the context of COVID-19. World Heal Organ. 2020;(December):1-10. 